\title{
PENGARUH FAKTOR LINGKUNGAN DAN STRATEGI PEMASARAN TERHADAP KINERJA PEMASARAN PADA UMKM DI LAMPUNG BARAT
}

\author{
Neli Anggraini ${ }^{1}$ Vicky.F Sanjaya ${ }^{2}$ \\ Universitas Islam Negeri Raden Intan Lampung \\ anggrainineli80@gmail.com¹ vicky@,radenintan.com²
}

\begin{abstract}
abstrak Faktor lingkungan dan strategi pemasaran merupakan salah satu untuk mengukur keberhasilan sebuah usaha karena merupakan variabel ini diyakini mampu untuk meningkatkan kinerja pemasaran pada pada usaha mikro kecil dan menengah (UMKM). Tujuan penelitian ini bertujuan untuk mengetahui pengaruh faktor lingkungan dan strategi pemasaran terhadap kinerja pemasaran pada UMKM. Dan untuk pengumpulan data melalui kuesioner yang disebar kepada responden. Sampel dalam penelitian ini berjumlah 60 Responden. Uji Statistik dilakukan dengan menggunakan Smart PLS 3, dari dua hipotesis yang diajukan satu faktor lingkungan yang berpengaruh positif tetapi tidak signifikan terhadap kinerja pemasaran, dan yang kedua strategi pemasaran berpengaruh positif dan signifikan terhadap kinerja pemasaran.
\end{abstract}

Kata kunci : Faktor Lingkungan dan Strategi Pemasaran Terhadap Kinerja Pemasaran

\section{THE EFFECT OF ENVIRONMENTAL FACTORS AND MARKETING STRATEGIES ON MARKETING PERFORMANCE ON MSMES IN WEST LAMPUNG}

\author{
Neli Anggraini ${ }^{1}$ Vicky.F Sanjaya ${ }^{2}$ \\ Islam Negeri Raden Intan Lampung University \\ anggrainineli80@gmail.com¹ vicky@radenintan.com²
}

\begin{abstract}
Environmental factors and marketing strategies are one way to measure the success of a business because these variables are believed to be able to improve marketing performance in micro, small and medium enterprises (MSMEs). The purpose of this study was to determine the effect of environmental factors and marketing strategies on marketing performance in SMEs. And for data collection through questionnaires distributed to respondents. The sample in this study amounted to 60 respondents. Statistical tests were carried out using Smart PLS 3, from the two hypotheses proposed one environmental factor that had a positive but not significant effect on marketing performance, and the second, marketing strategy had a positive and significant effect on marketing performance.
\end{abstract}

Keywords: Environmental Factors and Marketing Strategy on Marketing Performance 


\section{PENDAHULUAN}

Secara umum keberadaan usaha mikro kecil dan menengah (UMKM) di Negara-negara berkembang dapat dikatakan sebagai tulang punggung perekonomian Negara. Keberadaan UMKM terbukti telah mampu menggerakkan perekonomian bangsa dan mengurangi jumlah pengangguran yang ada. Meski para UMKM memiliki beberapa keterbatasan namun pada kenyataannya mereka mampu bersaing. Bahkan pada saat kondisi perekonomian memburuk dan banyak perusahaan besar yang terancam bangkrut, para UMKM tetap mampu untuk bertahan hidup, kenyataannya ini menunjukkan kekuatan dari para UMKM sebenernya. Kekuatan UMKM ini muncul karena mereka telah mulai menerapkan visi kewirausahaan (entrepreneurial visions) sehingga mereka mampu membawa perusahaannya tumbuh dan berkembang serta memperoleh profitabilitas yang meningkat. Dalam menjalankan UMKM faktor lingkungan dan strategi pemasaran sangat berpengaruh tehadap kinerja pemasaran UMKM.

Lingkungan pemasaran merupakan komponen kekuatan-kekuatan di luar aspek pemasaran yang dapat mempengaruhi kemampuan manajemen dalam membangun dan memelihara hubungan dengan pelanggan yang terdiri dari lingkungan eksternal (makro) dan internal (mikro). Strategi pemasaran juga sangat penting diterapkan pada semua bidang yang berkaitan dengan bisnis. Hal ini dikarenakana ketatnya persaingan di bidang bisnis menuntut semua pelaku bisnis berpikir secara kreatif dan inovatif untuk menarik perhatian banyak konsumen.

Lingkungan pemasaran atau lokasi tempat pemasarannya sudah ada yang tepat dan ada pula yang belum tepat. Proses pemasaran yang dilakukan oleh UMKM di Lampung Barat ini rata-rata memasarkan produknya dengan cara menjual langsung kepada konsumen dan para pelaku usaha ini juga sudah ada yang memanfaatkan teknologi dan informasi yang saat ini sedang berkembang untuk menjalankan usahanya dengan cara menjual produknya secara online menggunakan sosial media yang banyak dikenal masyarakat. Kinerja pemasaran merupakan ukuran keberhasilan perusahaan yang diukur pada jangka waktu yang telah ditentukan. Hasil ini dapat dikatakan sebagai aktivitas yang telah disusun dan dilaksanakan untuk mengidentifikasi apakah lingkungan dan strategi yang dibuat pelaksanaannya sudah tepat atau sebaliknya.

Berdasarkan penelitian sebelumnya yaitu Sarif Hidayat dan Murwatiningsih (2018) dalam penelitiannya yaitu pengaruh orientasi pasar dan kewirausahaan terhadap kinerja pemasaran melalui kapabilitas pemasaran pada UMKM lanting menyatakan bahwa perlu dilakukan penelitian selanjutnya dengan mengkaji variabel-variabel lain seperti faktor lingkungan dan strategi pemasaran terhadap kinerja pemasaran pada UMKM. Berdasarkan gap tersebut maka penulis ingin melanjutkan penelitian sebelumnya yaitu meneliti tentang pengaruh faktor lingkungan, dan strategi pemasaran terhadap kinerja pemasaran pada UMKM dan juga yang membedakan dengan peneliti 
E-ISSN $=$ 2621-7937

P-ISSN $=$ 2774-7026

sebelumnya yaitu terletak pada UMKM, dan lokasi penelitian yang berbeda. Penelitian ini bertujuan untuk mengetahui pengaruh faktor lingkungan dan strategi pemasaran terhadap kinerja pemasaran pada UMKM di Lampung Barat.

\section{KAJIAN TEORI}

\section{Faktor Lingkungan}

Definisi mengenai pengertian faktor lingkungan Menurut Munadjat Danusaputro Lingkungan adalah Semua benda dan kondisi termasuk di dalamnya manusia dan aktifitasnya, yang terdapat dalam ruang dimana manusia berada dan mempengaruhi kelangsungan hidup serta kesejahteraan hidup dan jasad renik lainnya.

\section{Menurut Emil Salim}

Pengertian lingkungan menurut Salim diartikan sebagai segala benda, kondisi, keadaan dan pengaruh yang terdapat dalam ruangan yang kita tempat dan mempengaruhi hal yang hidup termasuk kehidupan manusia.

Menurut Jonny Purba Pengertian lingkungan hidup adalah wilayah yang merupakan tempat berlangsungnya bermacam-macam interaksi sosial antara berbagai kelompok beserta pranatanya dengan simbol dan nilai.

Menurut Amsyari (1998) pengertian lingkungan terbagi atas 3 kelompok dasar. Yang pertama lingkungan fisik yaitu segala sesuatu yang ada disekitar manusia yang terbentuk dari benda mati,misalnya yakni udara, air, rumah, dan batu. Yang kedua lingkungan biologis yaitu segala unsur yang berada pada sekitar manusia yang menyerupai organisme hidup selain ada pada
Jurnal Ilmu Manajemen Saburai Vol 07, No 02, 2021

diri manusia itu sendiri, misalnya hewan dan tumbuhan. Yang ketiga lingkungan sosial yakni manusia-manusia yang lain yang berada di dalam lingkungan masyarakat.

Berdasarkan definisi diatas dapat ditarik kesimpulan bahwa lingkungan adalah segala sesuatu berupa semua benda, kondisi dan wilayah tempat berlangsungnya aktivitas atau interaksi sosial yang mempengaruhi kelangsungan hidup dan kesejahteraan manusia di dalam lingkungan masyarakat.

\section{Strategi Pemasaran}

Strategi pemasaran menurut Kotler (Kotler and Amstrong, 2012) adalah logika pemasaran dimana perusahaan berharap dapat menciptakan nilai bagi customer dan dapat mencapai hubungan yang menguntungkan dengan pelanggan

\section{Menurut Assauri (2012) strategi} pemasaran adalah Serangkaian tujuan dan sasaran, kebijakan dan aturan yang memberi arah kepada usaha-usaha pemasaran perusahaan dari waktu ke waktu, pada masing-masing tingkatan dan acuan serta alokasinya, terutama sebagai tanggapan perusahaan dalam menghadapi lingkungan dan keadaan persaingan yang selalu berubah.

Menurut Tjiptono (2011), menyatakan bahwa Strategi pemasaran adalah rencana yang hendak diikuti oleh manajer pemasaran. Rencana tindakan ini didasarkan atas analisa situasi dan tujuantujuan perusahaan dan merupakan cara untuk pencapaian tujuan tersebut.

Sedangkan menurut Kurtz (2008), pengertian strategi pemasaran adalah 
keseluruhan program perusahaan dalam menentukan target pasar.

Dari penjelasan diatas dapat disimpulkan bahwa strategi pemasaran adalah rencana menentukan pasar atau target dengan melihat situasi pasar seperti waktu, lokasi guna mencapai keuntungan atau tujuan yang di inginkan. Oleh kerena itu perusahaan dituntut untuk mampu menciptakan pemikiran baru atau ide dalam strategi pemasaran untuk meningkatkan kinerja pemasaran

\section{Kinerja Pemasaran}

Ferdinand ( 2000,p.23 ) , kinerja pemasaran adalah faktor yang digunakan mengukur dampak dari strategi yang diterapkan perusahaan. Strategi perusahaan selalu diarahkan menghasilkan kinerja pemasaran yang baik dan juga kinerja keuangan yang baik.

$$
\text { Pelham (1997) mengatakan tiga }
$$
indikator kinerja pemasaran adalah efektivitas perusahaan, pertumbuhan penjualan dan pertumbuhan keuntungan relatif, dalam penelitiannya juga menduga ada hubungan yang signfikan antara orientasi pasar dengan efektivitas perusahaan dan pertumbuhan penjualan yang pada akhirnya meningkatkan pertumbuhan keuntungan.

Tjptono (2008 : 239) kinerja pemasaran merupakan titik overspent dan underdelived, karena sulitnya mengukur efektivits dan efisiensi setiap aktivitas, keputusan atau program pemasaran.

Berdasarkan penjelasan diatas dapat disimpulkan bahwa kinerja pemasaran adalah suatu konsep untuk mengukur aktivitas proses pemasaran secara menyeluruh. Kinerja pemasaran dapat digunakan untuk mengukur sejauh mana efektivitas dan efisiensi pasar dapat dicapai suatu produk yang telah dihasilkan perusahaan.

\section{METODE PENELITIAN}

Jenis metode penelitian ini menggunakan metode kuantitatif karena hasil pengamatan dikonversikan kedalam angkaangka yang dianalisis menggunakan statistik. Menurut Creswell (2010: 27), penelitian kuantitatif mengharuskan peneliti untuk menjelaskan bagaimana variabel mempengaruhi variabel yang lain.

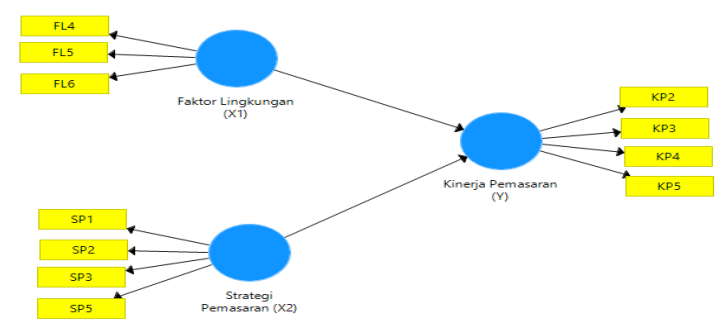

Gambar 1: Uji Vaiditas Sumber: Olah Data Smart PLS 3.0.

\section{Hasil Uji Validitas}

Menurut Ghozali (2009) menyatakan bahwa uji validitas digunakan untuk mengukur sah, atau valid tidaknya suatu kuesioner mampu untuk mengungkapkan sesuatu yang akan diukur oleh kuesioner tersebut. 
E-ISSN $=$ 2621-7937

P-ISSN $=$ 2774-7026

Berdasarkan hasil uji yang sudah dilakukan memiliki beberapa hasil diantaranya. Pertama terdapat item kuesioner yang gugur karena tidak memenuhi batas standar factor loading. Pada Konstruk Faktor Lingkungan dari 6 item tersisa 3 item, Konstruk Strategi Pemasaran dari 7 tersisa 4 item, dan Konstruk Kinerja Pemasaran dari 5 tersisa 4.

Selanjutnya dilakukan pengujian ulang terhadap validitas konstruk sehingga didapat semua item indikator berada diatas standar nilai faktor loading diatas $>0.6$ dianggap valid (Hair et al.,2010).

Tabel 1

Uji Validitas

\begin{tabular}{llll}
\hline Item & $\begin{array}{l}\text { Faktor } \\
\text { Lingkungan }\end{array}$ & $\begin{array}{l}\text { Strategi } \\
\text { pemasaran }\end{array}$ & $\begin{array}{l}\text { Kinerja } \\
\text { pemasaran }\end{array}$ \\
\hline FL4 & 0.826 & & \\
FL5 & 0.713 & & \\
FL6 & 0.716 & & \\
KP2 & & & 0.681 \\
KP3 & & & 0.816 \\
KP4 & & & 0.679 \\
KP5 & & 0.740 & \\
SP1 & & 0.748 & \\
SP2 & & 0.792 & \\
SP3 & & 0.756 & \\
SP5 & & & \\
\hline
\end{tabular}

Sumber : Olah data Smart PLS 3.0

\section{HASIL UJI RELIABILITAS}

Menurut Ghozali (2009) menyatakan bahwa reliabilitas adalah alat untuk mengukur suatu kuesioner yang merupakan indikator dari perubahan atau konstruk. Suatu kuesioner dikatakan reliable atau handal jika jawaban seseorang terhadap pernyataan adalah konsisten atau stabil dari waktu ke
Jurnal Ilmu Manajemen Saburai

Vol 07, No 02, 2021

waktu. Reliabilitas suatu test merujuk pada derajat stabilitas, konsistensi, daya prediksi, dan akurasi. Pengukuran yang dapat menghasilkan data yang reliabel.

Berdasarkan hasil uji yang sudah dilakukan dapat dinyatakan bahwa data dari hasil kuesioner yang sudah di uji validitasnya itu merupakan data yang reliabel meskipun ada salah satu dari nilai cronbach alpha hanya 0,6 tetapi itu masih reliabel karena menurut Riduwan (2010:220). Uji reliabilitas instrumen penelitian menggunakan rumus cronbach alpha adalah rumus yang digunakan untuk menguji tingkat reliabilitas ukuran dimana suatu instrument dapat dikatakan handal (reliabel) bila memiliki koefisien keandalan atau alpha sebesar 0,6 atau lebih. Menurut Sugiyono (2012:220). Instrument dinyatakan reliabel bila koefisien reliabilitas minimal 0,6.

Tabel 2

Uji Reliabilitas

\begin{tabular}{lllll}
\hline Variabel & $\begin{array}{l}\text { Cronbach's } \\
\text { Alpha }\end{array}$ & rho_A & $\begin{array}{l}\text { Composite } \\
\text { Reliable }\end{array}$ & (AVE) \\
\hline FL & 0.616 & 0.620 & 0.797 & 0.568 \\
SP & 0.756 & 0.759 & 0.845 & 0.577 \\
KP & 0.732 & 0.747 & 0.833 & 0.557 \\
\hline \multicolumn{4}{r}{ Sumber }
\end{tabular}

Sumber : Olah Data Smart PLS 3.0

\section{Hasil Uji Hipotesis}

Pengujian hipotesis dilakukan berdasarkan hasil pengujian inner model (model struktural) yang meliputi outpur r-squere, koefisien parameter dan T-statistik. Untuk melihat apakah suatu hipotesis itu dapat diterima atau ditolak diantaranya dengan memperhatikan nilai signifikan antara konstrak, t-statistik dan p-values. Pengujian 
hipotesis penelitian ini dilakukan dengan bantuan softwere Smart PLS 3.0. nilai tersebut dapat dilihat dari hasil bootstrapping. Rules Of Tumb yang digunakan pada penelitian ini adalah Tstatistik >1.67065 dengan tingkat signifikansi $\quad \mathrm{p}$-values $0.05 \quad(5 \%) \quad$ dan koefisional bernilai positif.

Table 3 Uji Hipotesis

\begin{tabular}{llllll}
\hline Hipotesis & $\begin{array}{l}\text { Original } \\
\text { Sample } \\
(\mathrm{O})\end{array}$ & $\begin{array}{l}\text { Sample } \\
\text { Mean } \\
(\mathrm{M})\end{array}$ & $\begin{array}{l}\text { Standar } \\
\text { Deviation } \\
\text { (STDEV) }\end{array}$ & $\begin{array}{l}\text { T-Statistich } \\
(\mathrm{O} / \mathrm{STDEV})\end{array}$ & $\begin{array}{l}\mathrm{P} \\
\text { Values }\end{array}$ \\
\hline FL X KP & 0.254 & 0.243 & 0.144 & 1.764 & 0.078 \\
SP X KP & 0.521 & 0.549 & 0.117 & 4.460 & 0.000 \\
\hline
\end{tabular}

Sumber : olah data Smart PLS 3.0

\section{Hipotesis 1 : Faktor lingkungan berpengaruh positif tetapi tidak signifikan terhadap kinerja pemasaran UMKM}

Hipotesis pertama diduga faktor lingkungan berpengaruh positif tetapi tidak signifikan terhadap kinerja pemasaran. Berdasarkan hasil pengujian yang telah dilakukan didapatkan hasil bahwa faktor lingkungan berpegaruh positif tetapi tidak signifikan terhadap kinerja pemasaran, dikarenakan menghasilan nilai original 0.254 , nilai T-Statistik sebesar 1.764 dan nilai p-values 0.078 . Hal ini dapat dibuktikan bahwa hipotsis faktor lingkungan sebagai variabel moderator mempengaruhi kinerja pemasaran tidak didukung. Hal ini sejalan dengan penelitian terdahulu yang dilakukan Arini Hidayah dan Purnadi (2017) dalam penelitian pengaruh strategi pemasaran dan orientasi wirausaha terhadap kinerja pemasaran yang dimoderasi oleh lingkungan persaingan pada industry batik sokaraja, kabupaten banyumas, menyatakan bahwa faktor lingkungan persaingan sebagai moderator tidak didukung atau ditolak.

\section{Hipotesis 2 : Strategi pemasaran berpengaruh positif dan signifikan terhadap kinerja pemasaran UMKM.}

Hipotesis kedua diduga strategi pemasaran berpengaruh positif dan signifikan terhadap kinerja pemasaran. Berdasarkan hasil pengujian yang telah dilakukan didapatkan hasil bahwa strategi pemasaran berpengaruh positif dan signifikan terhadap kinerja pemasaran, dikarenakan menghasilkan nilai original 0.521 , nilai T-statistik sebesar 4.460 , dan nilai p-values 0.000 . Hal ini dapat membuktikan bahwa hipotesis strategi pemasaran berpengaruh positif dan signifikan terhadap kenerja pemasaran didukung. Hal ini sejalan dengan penelitian yang dilakukan oleh Elwisam, Rahayu Lestari (2019) penerapan strategi pemasaran, inovasi produk kreatif dan orientasi pasar untuk meningkatkan kinerja pemasaran UMKM dalam penelitian menyatakan strategi pemasaran yang dilakukan para UMKM berpengaruh positif terhadap pengembangan usaha.

\section{PENUTUP}

\section{Kesimpulan}

Berdasarkan hasil penelitian dapat disimpulkan bahwa :

a. Faktor Lingkungan berpengaruh positif tetapi tidak signifikan terhadap kinerja pemasaran, dikarenakan menghasilan nilai original 0.254 , nilai T-Statistik sebesar 1.764 
E-ISSN $=$ 2621-7937

P-ISSN $=$ 2774-7026

dan nilai p-values 0.078. Hal ini dapat dibuktikan bahwa hipotsis faktor lingkungan sebagai variabel moderator mempengaruhi kinerja pemasaran tidak didukung.

b. Strategi pemasaran berpengaruh positif dan signifikan terhadap kinerja pemasaran, dikarenakan menghasilkan nilai original 0.521, nilai T-statistik sebesar 4.460, dan nilai p-values 0.000. Hal ini dapat membuktikan bahwa hipotesis strategi pemasaran berpengaruh positif dan signifikan terhadap kenerja pemasaran didukung.

\section{Saran}

Ada beberapa saran yang dapat digunakan untuk penelitian selanjutnya yaitu diperlukan penelitian lebih lanjut mengenai pengaruh faktor lingkungan dan strategi pemasaran terhadap kinerja pemasaran pada UMKM, dan peneliti menyarankan lebih baik jika menambahkan variabel bebas yang lainnya. Dan juga memperluas sampel atau responden yang sungguh-sungguh.

\section{DAFTAR PUSTAKA}

Hidayah, A., \& Purnadi. (2017). Dimoderasi Oleh Lingkungan Persaingan Pada Industri Batik Sokaraja , Kabupaten Banyumas. Seminar Nasional Riset Manajemen \& Bisnis 2017 "Perkembangan Konsep Dan Riset E-Business Di Indonesia, 2005, 182-192.

Khamidah, N. (2005). Analisis Pengaruh Faktor Lingkungan terhadap
Jurnal Ilmu Manajemen Saburai Vol 07, No 02, 2021

Inovasi Produk dan Kreativitas Strategi Pemasaran terhadap Kinerja Pemasaran. In Jurnal Sains Pemasaran Indonesia (Vol. 4, Issue 3, pp. 231-246). https://ejournal.undip.ac.id/index. php/jspi/article/view/13940

Eriyanafita, I. (2008). ANALISIS FAKTORFAKTOR SEBAGAI VARIABEL MODERAT ( Studi pada industri kerajinan batik di Pekalongan).

Lestari, R., \& Elwisam. (2019). Penerapan Strategi Pemasaran, Inovasi Produk Kreatif dan Orientasi Pasar Untuk Meningkatkan Kinerja Pemasaran UMKM. Jurnal Riset Manajemen dan Bisnis (JRMB) Fakultas Ekonomi UNIAT, JRMB Vol. 4, No 2, Juni 2019: $277-286$

Listyarso, A. (2005). Pengaruh Strategi Pemasaran Terhadap Kinerja Pemasaran dan Kinerja Perusahaan Dengan Lingkungan Persaingan Sebagai Variabel Modersting

Sucitro, R. (2002). Pengaruh Lingkungan Pemasaran Terhadap Kinerja Pemasaran Melalui Strategi Pemasaran Pada Usaha Jasa Laundry Di Surabaya. Jurnal Sains Pemasaran Indonesia, 1(1), $1-6$. 